\title{
Cattle and Calf Losses to Predators-Feeder Cattle Enterprises in the United States
}

\section{KERRY GEE}

\begin{abstract}
National losses to predators of beef cattle and calves on farms and ranches with 20 or more cows and market feeder calves or yearlings were investigated. Data are from a sample survey of about 1,800 producers in five major feeder cattle regions. Losses to dogs, coyotes, and all other predators were estimated. Percentage losses are small, but financial losses reach into millions of dollars.
\end{abstract}

Predators, particularly coyotes, are a concern to many livestock producers in the United States. Periodic reports of predator losses by cattlemen have attested to the existence of a problem for this industry, although its magnitude has not been known. Sheep and lamb losses to this cause have already been quantified. The Economics, Statistics and Cooperatives Service (ESCS), U.S. Department of Agriculture estimate 1974 losses to coyotes alone at more than 1.25 million lambs and adult sheep in 15 Western States with a value in excess of $\$ 27$ million (Gce et. al. 1977). Predator problems have also been identified as an important contributing factor in the declining Western States sheep population (Gee et. al. 1977).

\section{Methods}

In view of the deficiency in cattle and calf loss data, ESCS included questions on this subject as part of a comprehensive industry survey in $1976 .{ }^{1}$ Numbers compiled through personal interviews with a random sample of about 1,800 farmers and ranchers represented 1975 calendar year losses. Sample design and data collection were by the Statistics Division, ESCS.

The population of beef cattle producers included all those in major feeder cattle producing regions of the continental United States with 20 or more beef breeding cows who marketed feeder calves or yearlings during 1975. This excluded farms where

The author is agricultural economist, Economics, Statistics, and Cooperatives Service, U.S. Department of Agriculture, stationed at Colorado State University, Fort Collins.

Manuscript received March 17, 1978

This project was completed by the Commodity Economic Division's Meat Animal Research Group consisting of Roy Van Arsdall of the University of Illinois, Calvin Boykin at Texas A and M University, Henry Gilliam at North Carolina State University, and the author. cattle are fed for slaughter and farms with no beef breeding cows. The ESCS has identified five feeder cattle regions (Fig. 1). These include all continental States except 11 in the Northeast, which have only a small proportion of the nation's beef cattle inventory. The population as defined for estimating losses to predators included supplement for 1975, Stat. Bull. No. 522, June 1976. businesses, U.S. beef cattle regions, 1975 .

Loss of cattle weighing 500 pounds or more.

- Loss of calves prior to weaning.
$80 \%$ of total beef breeding cows in the 50 States. Numbers for each region are in Table 1.

The survey questionnaire, designed to gather information on management practices, production, and costs as well as inventories and losses, was filled out by professional U.S. Dep. Agr. enumerators during personal interviews with producers. Interviews were conducted in January 1976. Loss estimates called for in the questionnaire included number of cattle and calves lost to all causes, disease, theft, dogs, coyotes, and other predators. Cattle were defined as those weighing 500 pounds

Table 1. Numbers of beef breeding cows in survey population and United States, 1975.

\begin{tabular}{lcc}
\hline $\begin{array}{c}\text { Geographical } \\
\text { area }\end{array}$ & $\begin{array}{c}\text { Beef cows in herds of } \\
\text { 20 head or more where feeder } \\
\text { calves and yearlings (1,000 head) } \\
\text { are produced }\end{array}$ & $\begin{array}{c}\text { Total } \\
\text { beef } \\
\text { cows (1,000 head) }\end{array}$ \\
\hline Region & & \\
Southeast & 9,368 & 10,959 \\
Northcentral & 6,041 & 10,459 \\
Great Plains & 7,193 & 8,413 \\
Southwest & 10,477 & 11,004 \\
West & 3,414 & 3,865 \\
$\quad$ All regions & 36,493 & 44,700 \\
Outside of regions & & 772 \\
U.S. total & & 45,472 \\
\hline
\end{tabular}

Source: Compiled from numbers reported in U.S. Dep. Agr., Econ. Res. Serv., Livestock and Meat Statistics-

Table 2. Farms and ranches reporting beef cattle and calf losses to predators, feeder cattle

\begin{tabular}{|c|c|c|c|c|c|c|}
\hline \multirow[b]{2}{*}{$\begin{array}{c}\text { Cause } \\
\text { of } \\
\text { loss }\end{array}$} & \multicolumn{6}{|c|}{ Region } \\
\hline & $\begin{array}{l}\text { South- } \\
\text { east }\end{array}$ & $\begin{array}{l}\text { North- } \\
\text { Central }\end{array}$ & $\begin{array}{l}\text { Great } \\
\text { Plains }\end{array}$ & $\begin{array}{l}\text { South- } \\
\text { west }\end{array}$ & West & All regions \\
\hline & \multicolumn{6}{|c|}{$\begin{array}{l}\text { Percent of farms and ranches } \\
\text { Cattle }\end{array}$} \\
\hline Dog & 1 & 3 & 3 & 1 & 2 & 1 \\
\hline Coyote & 3 & & 1 & 1 & 2 & 1 \\
\hline \multirow[t]{2}{*}{ Other predators } & 3 & 3 & 3 & 3 & 3 & 3 \\
\hline & \multicolumn{6}{|c|}{ Calves ${ }^{2}$} \\
\hline Dog & 10 & 4 & 2 & 4 & 1 & 4 \\
\hline Coyote & 2 & 6 & 14 & 15 & 27 & 12 \\
\hline Other predators & 4 & & 1 & 4 & 2 & 2 \\
\hline
\end{tabular}

Values greater than zero but less than one when rounded to whole numbers. 
Table 4. Cattle and calf losses to various causes as a proportion of total losses, feeder cattle businesses, U.S. beef cattle regions, 1975 .

\begin{tabular}{|c|c|c|c|c|c|c|}
\hline \multirow[b]{2}{*}{$\begin{array}{c}\text { Cause of } \\
\text { loss }\end{array}$} & \multicolumn{6}{|c|}{ Region } \\
\hline & $\begin{array}{l}\text { South- } \\
\text { east }\end{array}$ & $\begin{array}{l}\text { North- } \\
\text { central }\end{array}$ & $\begin{array}{l}\text { Great } \\
\text { Plains }\end{array}$ & $\begin{array}{l}\text { South- } \\
\text { west }\end{array}$ & West & All regions \\
\hline & \multicolumn{6}{|c|}{ Percent of cattle losses ${ }^{1}$} \\
\hline Dog & 1 & 3 & 3 & 1 & 3 & 3 \\
\hline Coyote & 3 & & 3 & 1 & 1 & 3 \\
\hline Other predators & 2 & 3 & 3 & 2 & 3 & 1 \\
\hline All predators & 3 & 3 & 1 & 4 & 1 & 2 \\
\hline All other causes & 97 & 100 & 99 & 96 & 99 & 98 \\
\hline \multirow[t]{2}{*}{ Total losses } & 100 & 100 & 100 & 100 & 100 & 100 \\
\hline & \multicolumn{6}{|c|}{ Percent of calf losses ${ }^{2}$} \\
\hline Dog & 13 & 2 & 3 & 2 & 4 & 2 \\
\hline Coyote & 3 & 4 & 4 & 22 & 9 & 8 \\
\hline Other predators & 4 & & 3 & 5 & 3 & 1 \\
\hline All predators & 20 & 6 & 5 & 29 & 13 & 11 \\
\hline All other causes & 80 & 94 & 95 & 71 & 87 & 89 \\
\hline Total losses & 100 & 100 & 100 & 100 & 100 & 100 \\
\hline
\end{tabular}

${ }^{1}$ Loss of cattle weighing 500 pounds or more.

- Loss of calves prior to weaning.

"Values greater than zero but less than one when rounded to whole numbers.

Table 5. Estimated numbers and value of cattle and calf losses to predators, feeder cattle businesses, U.S. beef cattle regions, 1975 .

\begin{tabular}{|c|c|c|c|c|c|c|}
\hline \multirow[b]{2}{*}{ Item } & \multicolumn{6}{|c|}{ Region } \\
\hline & $\begin{array}{l}\text { South- } \\
\text { east }\end{array}$ & $\begin{array}{l}\text { North- } \\
\text { central }\end{array}$ & $\begin{array}{l}\text { Great } \\
\text { Plains }\end{array}$ & $\begin{array}{l}\text { South- } \\
\text { west }\end{array}$ & West & All regions \\
\hline & \multicolumn{6}{|c|}{1,000 head of cattle } \\
\hline Dog & 3.3 & .3 & .2 & .9 & .3 & 5.0 \\
\hline Coyote & .3 & & .5 & 2.2 & .6 & 3.6 \\
\hline Other predators & 5.2 & .3 & .2 & 4.4 & 2 & 10.1 \\
\hline \multirow[t]{2}{*}{ Total } & 8.8 & .6 & .9 & 7.5 & .9 & 18.7 \\
\hline & \multicolumn{6}{|c|}{1,000 head of calves } \\
\hline Dogs & 41.2 & 5.2 & 2.5 & 5.9 & 8.7 & 63.5 \\
\hline Coyote & 8.3 & 13.1 & 27.4 & 67.4 & 16.9 & 133.1 \\
\hline Other predators & 12.3 & & 2.5 & 14.8 & .6 & 30.2 \\
\hline \multirow[t]{2}{*}{ Total } & 61.8 & 18.3 & 32.4 & 88.1 & 26.2 & 226.8 \\
\hline & \multicolumn{6}{|c|}{1,000 dollars cattle and calves ${ }^{1}$} \\
\hline Dog & $5,536.5$ & 673.5 & 335.9 & 885.6 & $1,083.0$ & $8,514.5$ \\
\hline Coyote & $1,036.2$ & $1,532.7$ & $3,314.3$ & $8,363.2$ & $2,107.5$ & $16,353.9$ \\
\hline Other predators & $2,567.5$ & 65.1 & 335.9 & $2,686.4$ & 70.2 & $5,725.1$ \\
\hline Total & $9,140.2$ & $2,271.3$ & $3,986.1$ & $11,935.2$ & $3,260.7$ & $30,593.5$ \\
\hline
\end{tabular}

' Based on national weighted average 1975 prices per head for cattle and calves.

"Less than 1 when rounded to one decimal place.

where dogs become the greatest problem (Gee 1977).

\section{Magnitude of Losses}

Predators killed less than $1 \%$ of the January 1 inventory of beef cattle in the survey population weighing 500 pounds or more. Calf deaths to this cause between birth and weaning were about $1 \%$ of calves born alive. In the West and Southwest regions, calf losses exceed the average, reaching $3.7 \%$ and $1.3 \%$, respectively. Most producers with calf kills lose less than $5 \%$ of their calf crop to any one preda- tor (Table 3). This is much less than with sheep, where about one-third of producers lose in excess of $5 \%$ and one-fourth lose more than $10 \%$ of their lamb crop to coyotes (Gee July, 1977).

Losses to predators are not great when measured as a percentage of total losses among cattle and calves (Table 4). Just $2 \%$ of all cattle deaths and $11 \%$ of calf deaths prior to weaning are from this source. In two regions predators cause a much larger percentage of total calf loss: the Southeast $(20 \%)$ due to the influence of dogs, and the Southwest (29\%) because of coyotes.

\section{Value of Losses}

Estimated numbers of beef cattle and calves in the survey population killed by predators in 1975 are 18.7 thousand and 226.8 thousand, respectively, for a total of 245.5 thousand head (Table 5).

Deaths of beef cattle and calves may seem unimportant when expressed as percentages. But the total value lost by producers, $\$ 31$ million, is impressive (Table 5). ${ }^{2}$ Slightly over $\$ 16$ million is attributed to coyotes and nearly $\$ 9$ million to dogs. Financial loss from coyotes is more than one-half of that lost to this predator by western sheep producers in 1974 (\$27 million). Cattle and calf loss to all predators is probably within $10-15 \%$ of the value of Western sheep and lambs lost to all predators, although precise dollar estimates for the latter value have not been made.

\section{Discussion}

These estimates of cattle and calf losses to predators are based on the sample survey method which relies on producer judgment of numbers lost to each cause. In addition to normal sampling errors, errors in estimation may occur due to deficiencies in producer memory and incorrect diagnosis as to cause of death. However, it is assumed that these errors are off-setting. There are as many producers who underestimate losses to a particular cause as there are producers who overestimate these numbers. It is important to recognize this assumption when using data collected through this method. The cost of eliminating these sources of error is so great as to be prohibitive in estimating industry losses where large samples are necessary.

Cattle are valued at $\$ 217$ and calves $\$ 117$ per head Weights are assumed to be 1,000 pounds, 650 pounds, and 450 pounds for mature cattle, ycarlings, and calves, respectively. Prices are based on numbers for 1975 published in U.S. Dep. Agr., Econ. Res. Serv. Livestock and Meat Statistics-Supp. for 1976. Stat. Bull. No. 522, June 1977

\section{Literature Cited}

Gee, C.K., 1977. Lamb and stock sheep losses in northcentral states 1975. U.S. Dep. Agr., Econ. Res. Serv., CED working paper. 23 p. Gee, C.K., R.S. Magleby, W.R. Bailey, R.L. Gum, and L.M. Arthur. 1977. Sheep and lamb losses to predators and other causes in the western United States. U.S. Dep. Agr. Econ. Res. Serv., Agr. Econ. Rep. No. 369. 41 p. Gee, C.K. 1977. Frequency distributions based on lamb and stock sheep losses-western United States 1974. U.S. Dep. Agr., Econ. Res. Serv., NRED working paper No. 32.33 p.

Gee, C.K., R.S. Magleby, D.B. Neilson, D.M. Stevens, 1977. Factors in the decline of the western sheep industry. U.S. Dep. Agr., Econ. Res. Serv., Agr. Econ. Rep. No. 377. 